\title{
SPRAWOZDANIE
}

"Studia Wyborcze”, tom 27, 2019

DOI: https://doi.org/10.26485/SW/2019/27/8

\section{SPRAWOZDANIE Z OBCHODÓW ŚWIATOWEGO DNIA WYBORÓW, TORUŃ 7 LUTEGO 2019 ROKU}

Podczas Konferencji Światowych Organizacji Wyborczych (Global Elections Officials - GEO) we wrześniu 2005 roku w Siófok na Węgrzech postanowiono, że w pierwszy czwartek lutego każdego roku będzie obchodzony Światowy Dzień Wyborów (Global Elections Day - GED). Termin ten został wybrany z uwagi na to, że w okolicach tego dnia przypadają rocznice uchwalenia bądź podpisania większości umów międzynarodowych dotyczących kwestii wyborczych. Ideą święta jest umacnianie demokracji, poszerzanie wiedzy wyborczej wyborców oraz promowanie powszechnego udziału w głosowaniu - ze szczególnym uwzględnieniem osób głosujących po raz pierwszy oraz osób niepełnosprawnych i starszych, które z przyczyn od siebie niezależnych nie mogą wziąć udziału w akcie głosowania.

Tegoroczne obchody Światowego Dnia Wyborów odbyły się w Polsce 7 lutego 2019 roku na Uniwersytecie Mikołaja Kopernika w Toruniu.

Po roku od wejścia w życie znowelizowanego Kodeksu wyborczego, który wzbudza wiele bardzo zasadnych wątpliwości, mieli okazję spotkać się przedstawiciele Państwowej Komisji Wyborczej, komisarze wyborczy, przedstawiciele licznych środowisk naukowych zajmujący się tematyką wyborczą, dyrektorzy zespołów i delegatur Krajowego Biura Wyborczego, studenci oraz doktoranci. Obchody dowiodły, po raz kolejny, niezmierne znaczenie wyborów dla demokratycznego państwa prawnego. Potwierdziły także potrzebę przestrzegania w procesie wyborczym, przez wszystkich jego uczestników, pewnych granic wyznaczonych przede wszystkim przez przepisy prawa, ale także przez zwykłą przyzwoitość. Spotkanie było okazją do dyskusji przedstawicieli różnych dyscyplin naukowych oraz praktyków na temat zmian wprowadzonych nowelizacją Kodeksu wyborczego oraz pozwoliły na dokonanie podsumowania zastosowania tych regulacji w przeprowadzonych w 2018 roku wyborów samorządowych.

W tegorocznych obchodach Światowego Dnia Wyborów Państwową Komisję Wyborczą reprezentowali: sędzia Sylwester Marciniak, zastępca przewodniczącego PKW, sędzia Krzysztof Strzelczyk oraz minister Magdalena 
Pietrzak, Szef Krajowego Biura Wyborczego, sekretarz Komisji. Obecni byli również: liczne grono komisarzy wyborczych oraz dyrektorów delegatur Krajowego Biura Wyborczego, dyrektor Biura Parlamentu Europejskiego w Warszawie (Jacek Safuta), przedstawiciel ODIHR (Alexander Shlyk), naukowcy zajmujący się wyborami z różnych ośrodków akademickich, m.in. Gdańska (prof. dr hab. Andrzej Szmyt, prof. dr hab. Piotr Uziębło), Lodzi (prof. dr hab. Anna Rakowska-Trela, mgr Magdalena Wrzalik), Wrocławia (prof. dr hab. Andrzej Antoszewski), Torunia (prof. dr hab. Bartłomiej Michalak, prof. dr hab. Marek Sobczyk, dr Maciej Serowaniec, dr Anna Frydrych-Depka, dr Wojciech Peszyński, dr Arleta Hrechorowicz), Bydgoszczy (dr Marta Czakowska, dr Agata Pyrzyńska, mgr Michał Czakowski).

Pierwszym wydarzeniem w ramach obchodów Światowego Dnia Wyborów było seminarium zorganizowane przez Studenckie Koło Naukowe Prawa Wyborczego „Elektor” Uniwersytetu Mikołaja Kopernika w Toruniu. Koło, w związku ze Światowym Dniem Wyborów, zrealizowało projekt pt. Jak promować udziat w wyborach do Parlamentu Europejskiego. Jego celem było przedstawienie tzw. wyborcom pierwszego razu (first time voters) najważniejszych i szczególnie interesujących zagadnień związanych ze zbliżającymi się eurowyborami. W jego ramach miały miejsce wystąpienia studentów dotyczące wybranych zagadnień systemu wyborczego do Parlamentu Europejskiego, w tym zwłaszcza czynnego prawa wyborczego i znaczenia frekwencji wyborczej, w tym kampanii profrekwencyjnej. Odniesiono się do obecnie istotnych problemów prawa wyborczego. Malwina Jaskólska zaprezentowała podstawowe założenia systemu wyborczego do Parlamentu Europejskiego; Jan Janukowicz omówił zagadnienie frekwencji wyborczej w nadchodzących wyborach. Kolejno głos zabrał Michał Kołbuc, który wygłosił referat pt. Kampanie profrekwencyjne w wyborach do Parlamentu Europejskiego. Przeprowadzono również debatę studencką w stylu oksfordzkim, w której udział wzięli studenci dwóch ośrodków naukowych - Uniwersytetu Mikołaja Kopernika w Toruniu oraz Uniwersytetu Humanistyczno-Przyrodniczego im. Jana Długosza w Częstochowie, a także dyskusję uczestników z ekspertami o wyborach i europarlamencie.

Tegoroczna edycja projektu była częścią kampanii Tym razem głosuję, realizowanej we wszystkich państwach członkowskich Unii Europejskiej przez Biura Parlamentu Europejskiego. Warto podkreślić, że wydarzenie uzyskało wsparcie Fundacji Amicus Universitatis Nicolai Copernici. Seminarium zostało poprowadzone przez mgr. Pawła Raźnego (CSW UMK). Wystąpieniom przysłuchiwali się eksperci, a głos zabrał: m.in.: Jacek Safuta, dyrektor Biura Parlamentu Europejskiego w Warszawie oraz dyrektorzy delegatur: Andrzej Dyla, Jacek Kraszewski, Sławomir Michalak. 
Posiedzenie Rady Programowej Centrum Studiów Wyborczych UŁ i Centrum Studiów Wyborczych UMK, w którym uczestniczyli przedstawiciele Państwowej Komisji Wyborczej i Krajowego Biura Wyborczego to kolejny punkt programu obchodów. Spotkaniu przewodniczył prof. dr hab. Andrzej Sokala, kierownik CSW Uniwersytetu Mikołaja Kopernika w Toruniu. Przedstawiciele obu Centrów podsumowali działalność i dokonania swoich jednostek, jednocześnie omawiając plany i możliwości ich rozwoju w najbliższym czasie, w szczególności w związku z wejściem w życie nowej ustawy o szkolnictwie wyższym. Najistotniejsze podnoszone kwestie dotyczyły, między innymi, wydania kolejnego już numeru „Studiów Wyborczych”, współpracy w roli komisji oceniającej prac nadesłanych przez uczestników drugiego etapu III edycji konkursu „Wybieram Wybory”. Na zakończenie posiedzenia członkowie Rady Programowej podziękowali sędziemu Wojciechowi Hermelińskiemu za wieloletnią współpracę, jako że w marca 2019 roku przestaje On wchodzić w skład Państwowej Komisji Wyborczej i tym samym pełnić funkcję przewodniczącego tego organu.

Tradycyjnie zwieńczeniem obchodów Światowego Dnia Wyborów był Wykład im. prof. dr. Wacława Komarnickiego. O niegodności wyborczej ograniczającej prawa wyborcze mówiła prof. dr hab. Anna Rakowska-Trela z Centrum Studiów Wyborczych i Katedry Prawa Konstytucyjnego Uniwersytetu Łódzkiego.

Na początku prelegentka skupiła się na wyjaśnieniu istoty tej instytucji oraz przedstawieniu rozwiązań ustrojowych innych państw, w których występuje instytucja tzw. niegodności wyborczej. Na wstępie zaznaczyła, że celem wykładu nie jest szczegółowa i całościowa analiza tego zagadnienia, ale ukazanie przyczyn wprowadzenia i istoty niegodności wyborczej, jej wariantów i pokrótce także ewolucji. Za główny cel postawiła sobie próbę udzielenia odpowiedzi na pytanie, czy wyborcy podobnie odczuwają potrzebę obowiązywania cenzusu czci i godności w sposób i stopniu zbliżonym do odczuwania takiej potrzeby przez prawodawcę. Wszystkie podniesione zagadnienia prof. dr hab. Anna Rakowska-Trela odniosła do praktyki różnych państw. Przywołała zestawienie sporządzone przez Piotra Chybalskiego w 2008 roku, wskazując przy tym na państwa takie jak Dania, Grecja, Holandia, Litwa, Ukraina czy Włochy. Podsumowując stwierdziła, że niegodność wyborcza ma bogatą historię w polskich rozwiązaniach ustrojowych, które pokrótce przytoczyła. We wnioskach końcowych przeglądu obecnego stanu prawnego w zakresie niegodności wyborczej w Polsce podniosła, że instytucja ta dotyczy zarówno czynnego, jak i biernego prawa wyborczego, wskazując na te wyłączenia. Na koniec jeszcze postawiła pytanie o stosunek społeczeństwa - wyborców do instytucji niegodności wyborczej, w szczególności w aspekcie wymogu niekaralności, przywołując 
dwa przypadki, w których odczucia wyborców rozmijają się z tymi idealnymi zamierzeniami prawodawcy.

W dyskusji odniesiono się do wniosków podniesionych przez prelegentkę oraz do wskazanych w podsumowaniu dwóch spraw, które zrodziły tak wiele wątpliwości, ale dowodzą, że pojmowanie z jednej strony przez prawodawcę, z drugiej zaś przez społeczeństwo (wyborców) pojęć godności i braku godności, zdaje się rozmijać. W dyskusji nawiązano również do dokonanych zmian w prawie wyborczym, wyrażając obawy odnośnie do sprawnego przeprowadzenia kolejnych wyborów w 2019 roku.

Na zakończenie ostatniej części Światowego Dnia Wyborów, prof. dr hab. Andrzej Sokala podziękował prelegentce za wygłoszony referat, wszystkim zaproszonym gościom i współpracownikom obu Centrów Studiów Wyborczych za przybycie oraz serdecznie zaprosił na kolejne obchody w 2020 roku.

Magdalena Wrzalik*

* ORCID: 0000-0003-4179-9659. 